\title{
RECRUITMENT PATTERN OF JUVENILE FISHES INTO PAMI RIVER ESTUARY (WEST PAPUA, INDONESIA)
}

\author{
Sasanti R. Suharti ${ }^{\star}$ and Hagi Yulia Sugeha \\ Research Centre for Oceanography - Indonesian Institute of Sciences, \\ Л. Pasir Putih 1, Ancol Timur, Jakarta. 11048, Indonesia \\ *e-mail: santi_rs02@yahoo.com
}

\begin{abstract}
Recruitment pattern of juvenile fishes into Pami River estuary, West Papua, Indonesia (S 00.80970, E. 134.06050), was studied from July to October 2005 . The study purposes were 1) to observe fish diversity in family level, 2) to observe fish abundance of each family, 3) to observe recruitment pattern related to abundance and tidal rhythm. Samples were collected using line transect method and identification procedure were done based on morphological characteristics. A total of 19 Families were identified, namely Acanthuridae, Ambassidae, Anguillidae, Apogonidae, Carangidae, Chlopsidae, Clupeidae, Congeridae, Elopidae, Engraulidae, Gerreidae, Gobiidae, Mugillidae, Platycephalidae, Callyonimidae, Siganidae, Syngnathidae, Terapontidae, Tetraodontidae. Fishes composition varied each month. Family of Gobiidae was the most dominant juvenile fishes recruiting during this study with $32 \%$, $69.5 \%, 84.3 \%, 71.3 \%$, respectively. Other 8 families (Ambassidae, Engraulidae, Elopidae, Chlopsidae, Siganidae, Syngnathidae, Congeridae, and Callyonimidae) had the lowest composition varied from $0.4 \%$ to $3.2 \%$. Three different patterns in abundance during the recruitment time of juvenile fishes, 1) early night (18.00-21.00) was represented by Ambassidae, Chlopsidae, Clupeidae, Gerreidae, Terapontidae, 2) mid-night (22.00-01.00) was represented by Callyonimidae, Congeridae, Engraulidae, Mugilidae, Platycephalidae, Tetraodontidae, and 3) late night (02.00-05.00) represented by Acanthuridae, Apogonidae, Carangidae, Elopidae, Gobiidae, Siganidae, Syngnathidae. However, the peak of abundance occurred at late night ( $>50$ specimens caught), and recruitment pattern of all juvenile fishes has been associated with tidal rhythm.
\end{abstract}

Keywords: Juvenile fishes, Diversity, Abundance, Recruitment pattern, Pami River estuary

\section{INTRODUCTION}

Indonesian waters is known as the center of marine mega-biodiversity in the world (Anonim, 2004). Many studies on the biodiversity in the tropic reported that Indonesian waters is potential for living habitat of marine fishes. It was recorded approximately 3200 fish species inhabiting this waters (Peristiwady, 2006). The Indian Ocean as a part of tropical Pacific contains at least 2500 fish species belonging to 162 families (Lieske and Myers, 1994). All species are distributed in different zones, from the deep ocean to the continental area. Studies on the taxonomy of teleost group have been done in the world, however most of these studies are based only on the adult fish specimen (Leis, 1991). Only few studies have been conducted for juvenile fishes, especially in the tropic
(Matsuura et al., 2000), for example Delsman, a Dutch scientist who carried out his study on larval fishes in Java Sea in early 1920 's, Jespersen investigated distribution of eel larvae (leptocephalus) in the Indo-Pacific in 1942, and Soewito and Schalk (1990) studied fish larvae in Banda Sea.

Recruitment mechanism of juvenile fishes from their spawning habitat in the open ocean to their nursery habitat in the coastal area is one important ecological event that need to be understood. The mechanism concerns with ecological information related to the behavior of juvenile fishes during coastal migration period and its association with coastal environmental condition (Arai et al., 1999; Sugeha et al., 2001). Besides, study on the recruitment of juvenile fishes also related to the marine population size and has been a great interest 
of many researchers (Doherty and Fowler, 1994; Caley et al., 1996). Interaction of various physical processes in the ecosystem occurs on spatial and temporal scales and has significant contribution to complex variability in recruitment mechanism of juvenile fishes to their nursery ground. Transport of pre-settlement in coastal waters may be strongly influenced by wind (Thorrold et al., 1994), current (Hare and Cowen, 1996), and topographic fronts (Kingsford et al., 1991). Recruitment mechanism of juvenile fishes may be associated with tidal rhythm, lunar period, light intensity, water temperature and salinity, rainfall, and also turbidity (Jonsson, 1991; McCleave et al., 1993; Sugeha et al., 2001). In contrast, a greater marine biodiversity also promises various and complex biological characters that each marine organism varies genetically depending on their species, genus, family, order, class, or even in many different taxon (Whitten et al., 1987). Counteract between biological and physical processes plays an important role in sustainability of marine and coastal ecosystem, especially in the tropic that more remote compare to the sub tropic and temperate area (Whitten et al., 1987). However, recruitment mechanism of juvenile fishes in the tropic has been little studied, except for the recruitment mechanism of juveniles of tropical anguillid eels in the central Indonesian waters (Arai et al., 1999; Sugeha et al., 2001). Therefore, we need to have an intensive study on the recruitment of juvenile fishes in Pami River estuary of Papua Island, eastern Indonesia.

Papua Island is a region accommodating an incredible marine biological richness and known for its great biological wealth (Allen and Swainston, 1993). Diversity of coastal fishes is reflecting in a wide variety of reproductive strait and life histories strategies. Majority research on fishes from this region was based on adult (Allen et al., 2003). Therefore, we focus our research on the juvenile stage of fishes that entering the coastal island, especially recruitment mechanism of juvenile fishes entering the mouth of Pami River.

This study site is an estuary of Pami River where it is recognized as the greatest river in the western part of Papua Island. Estuaries are categorized as a complex habitat for aquatic organisms to live because the rapid change in environmental factors such as water temperature, salinity and current (Williams and Thom, 2001). Estuary habitat supports fewer species than the adjacent aquatic environments such as ocean and freshwaters but estuarine organism has to perform higher adaptation related to their complex environmental condition. Beside such difficulties, estuarine habitat provides abundant food and substantial protection as a nursery ground for many marine larva and juvenile fishes. These habitats perform a variety of important functions within an ecosystem and play an important role in the life history and ecology of commercially and ecologically important resources (Segar, 1998). The link between a habitat and a species is generally demonstrated through feeding, refuge from predation, or support of reproduction (Williams and Thom, 2001; Segar, 1998).

Objectives of this study were firstly, to observe the diversity of juvenile fishes; secondly, to observe the fluctuation of juvenile fishes abundance; and thirdly, to know the environmental factors associated with recruitment of juvenile fishes in the estuary of Pami River.

\section{METHOD}

\section{Sampling time and location}

Sampling was carried out in the estuary of Pami River, West Papua (S 00 80970, E. $134^{\circ} 06050$, Fig. 1) on each new moon day, from July to October 2005. Adjustment of new moon day sampling was according to previous report on the recruitment timing of juvenile fishes in the tropic that strongly affected by lunar period, especially on the new moon day (Sugeha et al., 2001).

\section{Sampling technique}

Fishes were caught along a $10 \mathrm{~m}$ transect set in the beach within $1.5 \mathrm{~m}$ from the shore. Two triangular scoop nets with $100 \mathrm{~cm}$ in length and 75 $\mathrm{cm}$ (mouth $0.3 \mathrm{~m}^{2}, 1 \mathrm{~mm}$ mesh) were applied to collect the juvenile samples. The nets were fished simultaneously at depth ranging from 25 to $50 \mathrm{~cm}$, and 10 replications were made hourly (18:00 to 05:00) during sampling time. Surface water temperature and salinity in the estuary of Pami River were also recorded using thermometer and refractometer, respectively. Tidal data were following the table of tidal prediction in 2005 for the Indonesian region issued by Indonesian Navy.

\section{Identification procedure}

Samples of juvenile fishes were preserved immediately in $10 \%$ formalin, labelled and 


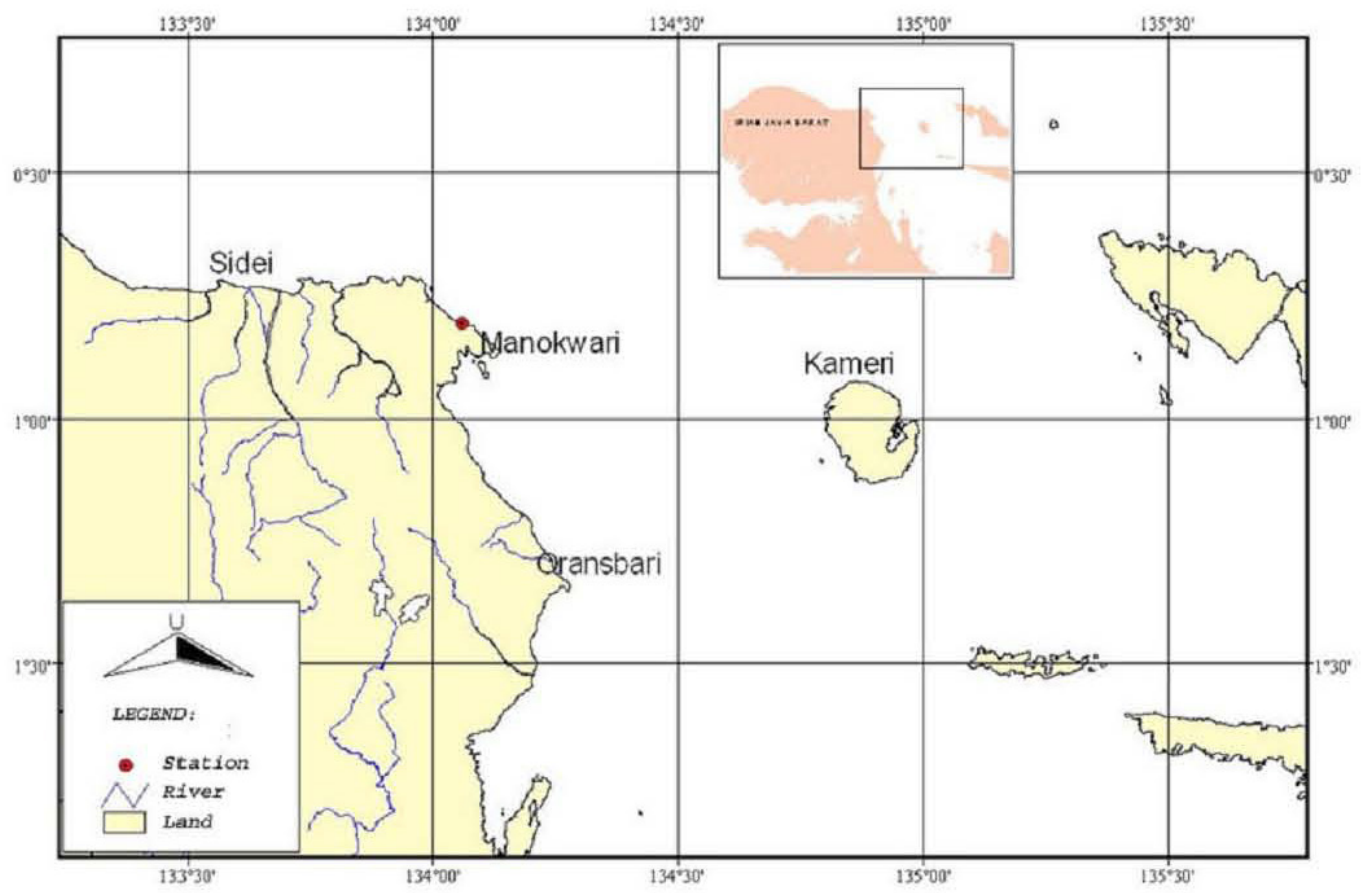

Figure 1. Location of study site at Pami Estuari, Manokwari, West Papua.

transported to the laboratory of Research Center for Oceanography-LIPI in Jakarta, for further analyses. At the laboratory, fish identification was taken based on external morphology characteristics (body shape) and meristic characters such as counting of fins (spines and rays). Several key identifications (Leis and Trnski, 1989; Neira et al. 1998; Leis and Carson-Ewart, 2000; Nakabo, 2002) were used to identify the fish samples collected in this study. A low power dissecting microscope was utilised to identify fish samples

\section{RESULTS}

\section{Family identification}

A total of 415 juvenile fishes comprised of 19 families were successfully identified in the present study. Based on body shape and meristic characters, each family was described and shown in Table 1.

\section{Family composition}

Family composition varied each month where the lowest was found in September (5 families), followed by July ( 7 families), August ( 9 families) and October (12 families) (Fig. 2 and Table 2). Family Gobiidae was the most dominant juvenile fishes recruiting from July to October with $32 \%$, $69.5 \%, 84.3 \%, 71.3 \%$, respectively. Other 8 fami- lies (Ambassidae, Engraulidae, Elopidae, Chlopsidae, Siganidae, Syngnathidae, Congeridae, and Callyonimidae had the lowest composition varied from $0.4 \%$ to $3.2 \%$. There was fluctuation in abundance of fish recruitment into Pami Estuary, such as for the whole night following tidal rhythm (4 families), at early night (3 families), at mid-night ( 6 families) and at late night or beginning of morning (6 families) (Fig. 3).

\section{Recruitment pattern}

Water temperature during this study ranged between $25^{\circ}$ and $29.5^{\circ} \mathrm{C}$, where the lowest was recorded in October and the highest was in July. For salinity, on the other hand, the lowest was recorded in July (10\%o), and the highest was found in July and August (35\%o). Tide was ranging between 0.5 and $1.7 \mathrm{~m}$ during the study, where the lowest also occurred in October and the highest tide was in September and October. Association between temperature and abundance of juvenile fishes during this study was not so clear and showed different pattern among sampling months. Similar result was also found in terms of association between salinity and abundance of juvenile fishes. On the other hand, tidal rhythm was more pronounce than other factors such as salinity and water temperature. Association between tidal 
Table 1. Description of fish family found in Pami River estuary, July-October 2005.

\begin{tabular}{|c|c|}
\hline Family & Characteristics \\
\hline Ambassidae & $\begin{array}{l}\text { a transparent fishes with deeply notched, single dorsal fin, and serrations on various head } \\
\text { bones. Large internal melanophore at nape. }\end{array}$ \\
\hline Gerreidae & protrusible jaws, dorsal fin long, single, deeply forked caudal fin \\
\hline Terapontidae & $\begin{array}{l}\text { body oblong or ovate and moderately deep, have two opercular spines, thoracic pelvic fins. } \\
\text { Melanophore series al ong ventral midine of tail }\end{array}$ \\
\hline Gobiidae & $\begin{array}{l}\text { small fishes with elongate to moderate robust body. Prominent gas bladder. One to many } \\
\text { melanophores along ventral midine of tail. }\end{array}$ \\
\hline Gupeidae & $\begin{array}{l}\text { body elongate and cylindrical to deep laterally compressed, have a single, short dorsal fin } \\
\text { near mid body, pelvic fins directly below or just behind the dorsal fin. Anal fin well behind the } \\
\text { origin of the last dorsal-fin rays. Dorsal and anal fins without spines. }\end{array}$ \\
\hline Engraulidae & $\begin{array}{l}\text { body elongate, snout projecting beyond the tip of the lower jaw. A short dorsal fin near } \\
\text { midbody, pelvic fin anterior, under or posterior to the dorsal fin. The anal fin varies in length. } \\
\text { Dorsal and anal fins without spines. Body lightly pigmented }\end{array}$ \\
\hline Syngnathidae & mostly slender, elongate fishes. Body composed of bony plates arranged in the form of rings \\
\hline Platycephalidae & $\begin{array}{l}\text { depressed head with bony ridges, two separate but adjacent dorsal fins, thoracic pelvic fins, } \\
\text { a short-based, spineless anal fin }\end{array}$ \\
\hline Apogonidae & moderately deep body, prominent eyes and two well separated, short-based dorsal fins. \\
\hline Carangidae & $\begin{array}{l}\text { strongly compressed and vary in shape from elongate and fusiform to deeply ovate. Have } \\
\text { two dorsal fins, the first two anal-fin spines separated from the third, a narrow caudal } \\
\text { peduncle. Well developed and extensive head spination. }\end{array}$ \\
\hline Mugilidae & $\begin{array}{l}\text { elongate with sub-cylindrical body, mouth small, terminal or inferior. Two short dorsal fin, } \\
\text { well separated, anal fin short, caudal fin emarginated or forked, and pectoral fin inserted high } \\
\text { on body. }\end{array}$ \\
\hline Acanthuridae & $\begin{array}{l}\text { high body, compressed fishes. Mouth small, low on head and terminal.Continuous dorsal fin } \\
\text { unnotched. Caudal fin truncate }\end{array}$ \\
\hline Siganidae & body oval, laterally compressed. Mouth very small, terminal. \\
\hline Callyonimidae & body scaleless, moderately depressed. Heavy pigmented fish. \\
\hline Tetraodontidae & $\begin{array}{l}\text { headlarge and blunt. Jaw form a beak with strong teeth. Dorsal and anal fin located far } \\
\text { posteriorly. Pelvic fin absent }\end{array}$ \\
\hline Eopidae & $\begin{array}{l}\text { body elongate. Fusiform, moderately compressed. All fins without spines. Dorsal fin begins } \\
\text { slightly behind midbody, anal fin short, caudal fin deeply fork, pectoral fin low on side of } \\
\text { body, pelvic fin abdominal }\end{array}$ \\
\hline Chlopsidae & $\begin{array}{l}\text { body moderately elongate, compressed, anus slightly before midbody. Snout moderate to } \\
\text { short, projecting slightly beyond tip of lower jaw. Dorsal and anal fins well developed, } \\
\text { confluent with caudal fin }\end{array}$ \\
\hline Congeridae & $\begin{array}{l}\text { body moderately to elongate, anus located at anteriorly half to third of total length. Dorsal } \\
\text { and anal fins present, confluent around tail }\end{array}$ \\
\hline Anguillidae & $\begin{array}{l}\text { a complete juvenile transparent of glass eel, tubular in body shape (anguilliform), dorsal and } \\
\text { anal fin connected in conjunction with rounded caudal fin. Early distribution of pigmentation } \\
\text { could be observed in the caudal tip, dorsal, and sometimes in the skull. }\end{array}$ \\
\hline
\end{tabular}

rhythm and abundance of juvenile fishes showed different patterns among months, but they still had a tendency that the highest recruitment occurred at the onset of high tide, except in July (Fig. 4).

\section{DISCUSSION}

Most of the fish recruit in the Pami River Estuary came from elsewhere of which the high proportion was coral reef fishes. Juvenile fishes may aggregate into this waters for feeding and growing temporary away from concentrations of adults to find shelter and prey resources. According to Segar (1998), estuaries are ideal habitats for larval and juvenile stages of marine organisms, because these habitats provide food and shelter. However, habitat requirements may change depending on the life historical stage. 

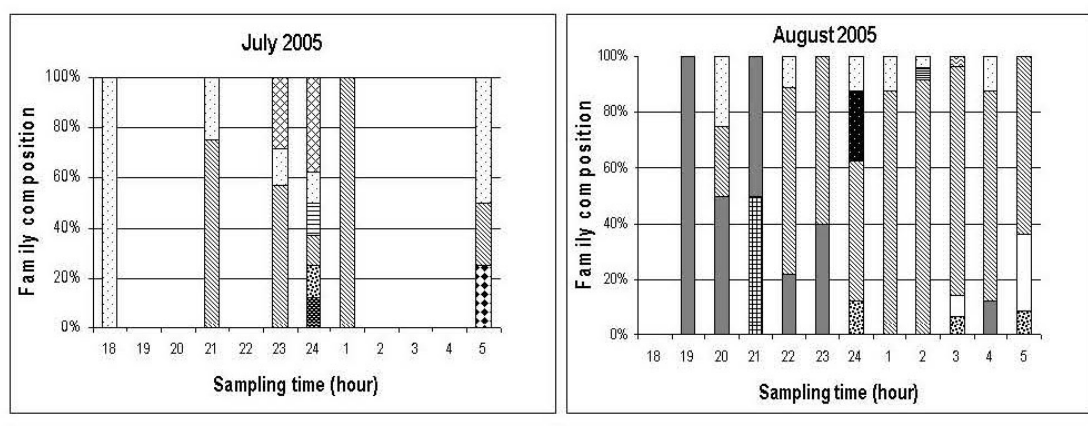

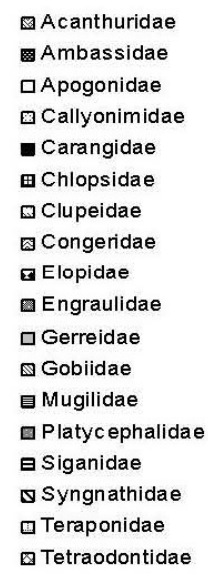

\begin{tabular}{|c|c|c|c|c|c|c|c|c|c|c|c|c|c|}
\hline \multirow{2}{*}{$\begin{array}{l}\text { Timing of } \\
\text { recruitment }\end{array}$} & \multirow{2}{*}{ Family } & \multicolumn{12}{|c|}{ Time of sampling /no of individual } \\
\hline & & 18 & 19 & 20 & 21 & 22 & 23 & 24 & 1 & 2 & 3 & 4 & 5 \\
\hline \multirow[t]{4}{*}{ Whole night } & Anguilidae & 2 & 12 & 5 & 3 & - & 8 & 11 & 8 & 12 & 18 & 8 & 9 \\
\hline & Ambassidae & 9 & - & - & - & 2 & - & 3 & 4 & 3 & 7 & - & - \\
\hline & Gerreidae & 1 & 3 & 4 & 3 & 3 & 2 & - & 1 & 1 & 3 & 3 & 3 \\
\hline & Syngnathidae & 1 & - & - & 1 & - & - & - & - & 1 & 1 & - & - \\
\hline \multirow[t]{3}{*}{ Early night } & Chlopsidae & - & - & - & 1 & - & - & - & - & - & - & - & - \\
\hline & Clupeidae & 8 & - & - & - & - & - & - & - & - & - & - & - \\
\hline & Terapontidae & 6 & - & 2 & 1 & 1 & 3 & 3 & 2 & 1 & - & 1 & - \\
\hline \multirow[t]{6}{*}{ Mid- night } & Callyonimidae & - & - & - & - & - & - & 1 & - & - & - & - & - \\
\hline & Congeridae & - & - & - & - & - & - & 1 & - & - & - & - & - \\
\hline & Engraulidae & - & - & - & - & - & - & 1 & 1 & - & - & - & - \\
\hline & Mugilidae & - & - & - & - & - & - & 1 & - & 1 & - & - & - \\
\hline & Platycephalidae & - & - & - & - & - & - & 2 & - & - & - & - & - \\
\hline & Tetraodontidae & - & - & - & - & - & - & 4 & 1 & - & - & - & - \\
\hline \multirow[t]{6}{*}{ Late night } & Acanthuridae & - & - & - & - & - & - & 1 & - & - & 2 & - & 1 \\
\hline & Apogonidae & - & - & - & 1 & 1 & - & - & 1 & 1 & 3 & - & 3 \\
\hline & Carangidae & - & - & - & - & - & - & - & - & - & 1 & - & 2 \\
\hline & Elopidae & - & - & - & - & - & - & - & 1 & - & - & - & 1 \\
\hline & Siganidae & - & - & - & - & - & - & - & - & 1 & - & - & - \\
\hline & Gobiidae & - & - & 2 & 9 & 14 & 15 & 29 & 21 & 89 & 72 & 16 & - \\
\hline
\end{tabular}

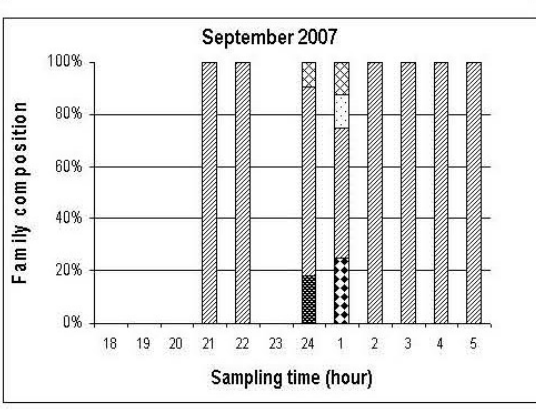

Figure 2. Family composition of juvenile fishes recruiting into Pami River estuary during the study (JulyOctober 2005). 
a)

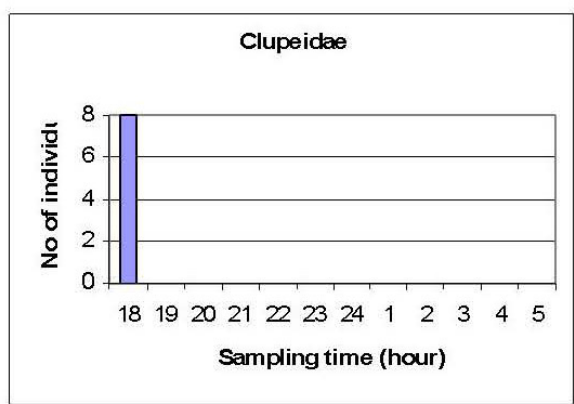

c)

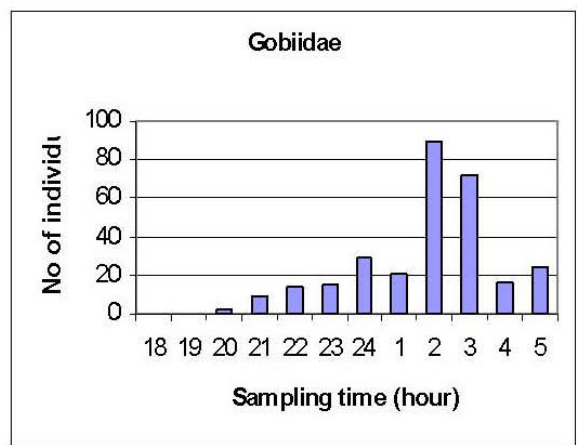

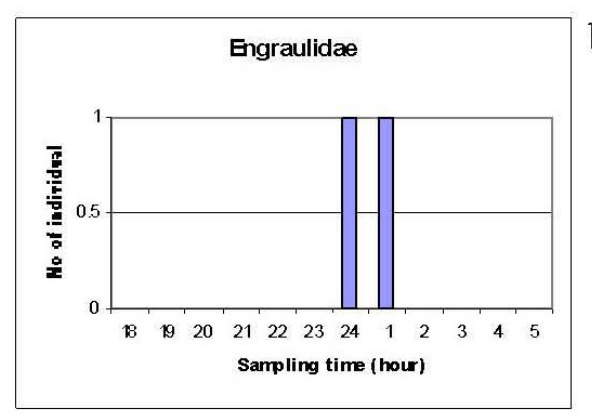

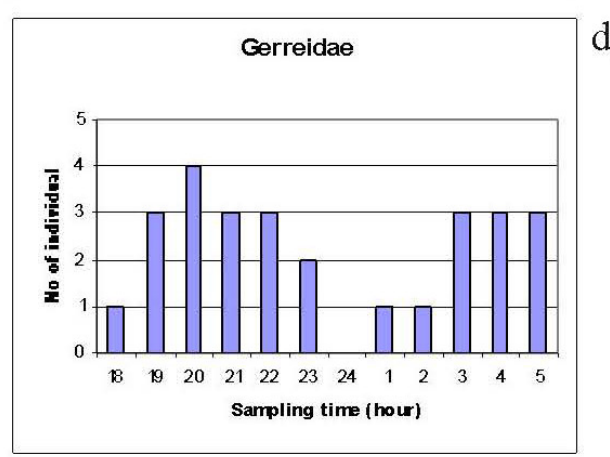

b)

d)

Figure 3. Patterns of abundance represented by one family in each pattern during the study (July-October 2005) in Pami River estuary. a) early night; b) mid-night; c) late night; d) whole of night.
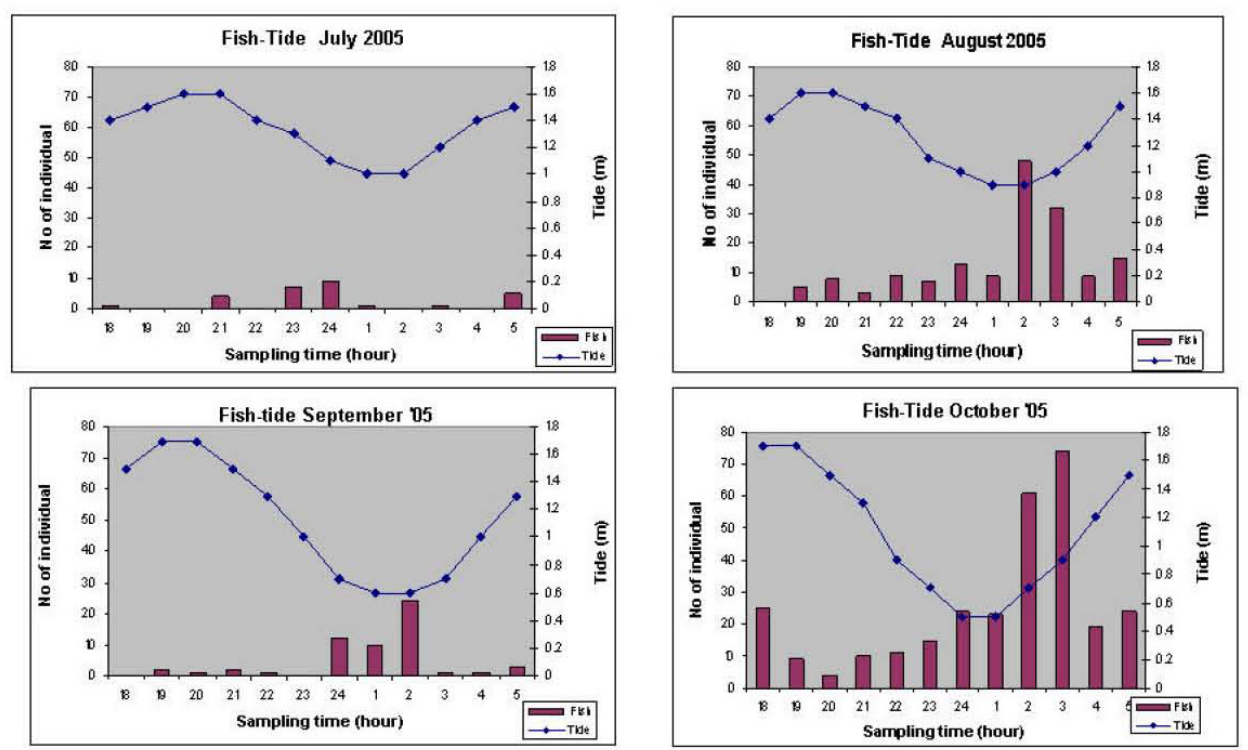

Figure 4. Pattern of recruitment in abundance and association with tidal rhythm of juvenile fishes during the study (July-October 2005) in Pami River estuary.

Transition between pelagic larval stage and juvenile during settlement can involve in changes of morphology as well as fundamental behavioral changes. Nineteen families of juvenile fishes were found to recruit consisted of Congeridae, Acanthuridae, Chlopsidae, Siganidae, Elopidae, Gobiidae, Clupeidae, Engraulidae, Callyonimidae, Platycephalidae, Syngnathidae, Tetraodontidae, Ambassidae, Anguillidae, Gerreidae, Terapontidae,
Apogonidae, Mugilidae, Carangidae. Gobiidae is the largest family of fishes and occupies variety of habitats. Therefore, it confirms with this finding of this study.

It is well understood that most marine fishes has bipartite life history, begining as a pelagic stage and followed by benthic stage (Leis, 1991). Pelagic larvae were drifted before settling as juvenile fish at a suitable location. This stage can vary between 
species, and it can be days to months, from meters to thousand kilometers, often distant from where they were spaw to find suitable environment before settlement (Kingsford and Finn, 1997; Cowen et al., 2000). Fish larvae were found to have capability for swimming and being able to regulate their distribution (Leis and McCormick, 2002). Furthermore, Leis and Carlson-Ewart (2002) investigated that at the late stage of larval development, they could orientate toward the island. Recruitment to local population seems an open input from other populations. Abundance of local population is independent of the rate of arrival recruitment. Leis (1991) found that strong wind could affect differences in abundant of individual taxa and an assemblage was generally found.

Settlement was known primarily nocturnal (Carr, 1998). Every species have a different temporal pattern of recruitment. It is clear in this study that the recruitment pattern into Pami Estuary was taxon specific, e.g. Gobiidae always commence to enter Pami Estuary at late night and had the highest recruitment at mid-night. Other example for recruitment with having different pattern showed that most fish swim toward the estuary at the onset of darkness and at the transition from dark to light phase. Recruitment of fishes in tropical waters is highly seasonal and most fish recruits throughout the year. On the other hand, species diversity in the Pami Estuary was an effect of different arrival of spatial pattern of new recruits. This is mostly due to survival rate of the recruitment.

Many factors affect the abundance of recruitments patterns, e.g. physical processes such as winds (Cowen, 1998) and topographic fronts (Kingsford et al., 1991). Association between oceanographic processes and biological aspects depend on capability of fish to respond to a given physical processes. Distribution pattern of early juvenile fishes is more stratified during the day and more uniform at night (Cowen, 1998; Leis, 1991). Pattern of recruitment of juvenile fishes into Pami Estuary was found highest at mid-night and coinciding with the onset of high tide. Increasing water flow might trigger juvenile fishes entering the estuary. This is the dynamic behavior of the juvenile fishes to choose the suitable time. This strategy used by juvenile fishes is more likely for surviving and might also to avoid predator. As mentioned earlier that the late stages of larvae are capable of orientation. Sponaugle et al. (2002) found in their observation that larvae retained near the bottom throughout tidal cycle or moving higher in the water column during flood than ebb tides. According to Clancy and Cobb (1997) larvae in near shore waters such estuaries and bays are primarily influenced by tidal current. Similar finding was also stated by Kingsford et al. (2002) that lunar and tidal rhythm may have associated with recruitment pulses. Fluctuation in abundance was more associated with tidal rhythm rather than salinity and water temperature, but showed different in timing of peak in abundance during this investigation. Thus, to increase the survival rate of fish juvenile, they should have an optimal strategy related to environmental conditions.

The diversity of fish juvenile in the estuary of Pami Rivers was detected during this study. However for further study, more samples should be taken monthly over the year for providing complete information on fish recruitment and diversity. The sampling time for recruitment study was also confirmed that samples should be collected at night on the new moon day.

\section{REFERENCES}

Allen, G.R., and R. Swainston. 1993. ReefFishes of New Guinea. Christensen Research Institute. Singapore, $132 \mathrm{pp}$.

Allen, G.R., R. Seene, P. Humann, and N. DeLoach, 2003. Reef Fish Identification. Tropical Pacific. New World Publications, Inc. Singapore, 480pp.

Anonim. 2004. Pedoman Umum. Pengelolaan Terumbu Karang. Departemen kelautan dan Perikanan. Coral Reef Rehabilitation and Management Program.

Arai T., J. Aoyama, D. Limbong., and K. Tsukamoto. 1999. Species composition and inshore migration of tropical eels, Anguilla spp., recruiting to the estuary of the Poigar River, Sulawesi Island. Mar. Ecol. Prog. Ser, 188: 299-303.

Caley, M.J., M. Carr, M.A. Hixon, T.P. Hughes, G.P. Jones, and B.A. Menge. 1996. Recruitment and the local dynamics of open marine populations. Annu. Rev. Ecol. Sys., 27: 477-500.

Carr, M. 1998. Defining and measuring 'recruitment': is the bandwagon headed straight to hell? In: ReeFish'95: Recruitment and Population Dynamics of Coral Reef Fishes. Jones, G.P., Doherty, P.J., Mapstone, B.D., and Howlett, L.(Eds), Townsville, Australia. p.132-134. 
Clancy, M., and J.S. Cobbs. 1997. Effect of wind and tidal advection on distribution patterns of rock crab Cancer irroratus megalopae in Block Island Sound, Rhode Island. Mar. Ecol. Prog. Ser., 152: 217-225.

Cowen, R.K. 1998. Scales of physical processes important to recruitment of coral reef fishes. In: ReeFish'95: Recruitment and Population Dynamics of Coral Reef Fishes. Jones, G.P., Doherty, P.J., Mapstone, B.D., \& Howlett, L.(Eds), Townsville, Australia. p. $67-72$

Cowen, R.K., K.M.M. Lwiza, S. Sponaugle, C.B. Paris, and D.B. Olson. 2000. Connectivity of marine population: open or closed? Science 287: 857-859.

Doherty, P. and T. Fowler. 1994. An empirical test of recruitment limitation in a coral reef fish. Science 263:935-939.

Hare, J.A., and R.K. Cowen. 1996. Transport mechanisms of larval and pelagic juvenile bluefish (Pomatomus saltatrix) from South Atlantic Bight spawning ground to Middle Atlantic Bight nursery habitats. Limnol. Oseanogr., 41: 1264-1280.

Jespersen, P. 1942. Indo-Pasific leptocephali of the genus Anguilla. Dana Rep 22: 1-128.

Jonsson, N. 1991. Influence of water flow, water temperature and light on fish migration in the river. Nordic. J. Fresh. Res., 66: 20-35.

Kingsford, M.J., E. Wolanski, and J.H. Choat. 1991. Influence of tidally induced fronts and Langmuir circulations $\mathrm{n}$ distribution and movements of presettlement fishes around a coral reef. Mar Biol., 109: 167-180.

Kingsford, M.J., and M. Finn. 1997. The influence of phase of the moon and physical processes on the input of presettlement fishes to coral reefs. J. Fish. Biol., 51 (Suppl.A): 176-205.

Kingsford, M.J., J.M. Leis, A. Shanks, K.C. Lindeman, S.G. Morgan, and J. Pineda. 2002. Sensory environments, larval abilities and local self-recruitment. Bul. Mar. Sci. 70(1) suppl.: 309-340.

Kuiter, R.H. 1992. Tropical Reef-Fish of the Western Pacific Indonesia and Adjacent Waters. PT. Gramedia Pustaka Utama. 328pp.

Leis, J.M. 1991. The pelagic stage of reef fishes: the larval biology of coral reef fishes. In: Sale, P. (Ed.), The Ecology of Fishes on Coral Reefs. Academic Press, San Diego, NY, pp.183-230.

Leis, J.M., and T. Trnski. 1989. The larvae of Indo_Pacific Shore Fishes. New South Wales University Press, Sydney, and University Hawaii Press, Honolulu. 371pp.

Leis, J.M., and B. Carson-Ewart. 2000. Fauna Malesiana handbook 2. The larvae of Indo-Pa- cific coastal fishes. An identification guide to marine fish larvae. Brill, Leiden. 850pp.

Leis, J.M. and B. Carson-Ewart. 2002. In situ settlement behaviour of damselfish (Pomacentridae) larvae. J. Fish. Biol., 61(2): 325-346.

Leis, J.M., and M. McCormic. 2002. The biology, behavior and ecology of the pelagic, larval stage of coral reef fishes. In: Sale, F (Ed), Coral Reef Fishes. Elsevier Science, USA., 171-198.

Lieske, E., and R. Myers. 1994. CoralReef Fishes. IndoPacific \& Caribbean. Harperr Collins Publisher. 400pp.

Matsuura, K., K. Sumadiharga, and K. Tsukamoto. 2000. Field Guide to Lombok Island. Identification Guide to Marine Organisms in Seagrass Beds of Lombok Island, Indonesia. Ocean Research Institute, Tokyo University. $449 \mathrm{pp}$.

McCleave, J.D. 1993. Physical and behavioural controls on the oceanic distribution and migration of leptocephali. J. Fish. Biol., 43: 243-284.

Nakabo, T. 2002. Fishes of Japan with Pictorial Key to the Species, English Edition. Tokay Univerity Press. 1681pp.

Neira, F.J., A. G. Miskiewicz, and T. Trnski. 1998. Larvae of Temperate Australian Fishes. Laboratory Guide for larval Fish Identification. Univ. of Western Australia Press. 474pp.

Segar, D.A. 1998. Introduction to Ocean Sciences. Wadsworth Publishing Company, New York, 359pp.

Soewito and P.H. Schalk. 1990. Spatial and seasonal patterns in fish larvae distribution in the Banda Sea (Indonesia). Netherlands Joumal of Sea Research, 25(4): 591-600.

Sponaugle, S., R.K. Cowen, A. Shanks, S.G. Morgan, J.M. Leis, J. Pineda, Boehlert, M.J. Kingsford, K.C. Lindeman, C. Grimes, and J.I. Munro. 2002. Predicting self-recruitment in marine populations: Biophysical correlates and mechanisms. Bull. Mar. Sci., 70(1) Suppl: 341-375.

Sugeha H.Y., T. Arai, M.J. Miller, D. Limbong, and K. Tsukamoto. 2001. Inshore migration of the tropical eels Anguilla spp recruiting to the Poigar River estuary on north Sulawesi Island. Mar. Ecol. Prog. Ser, 182: 283-293.

Peristiwady, T. 2006. Ikan-Ikan LautEkonomis Penting di Indonesia. Petunjuk Identifikasi. LIPI Press, Jakarta. 270pp.

Thorrold, S.R., J.M. Shenker, R. Jr. Mojica, E.D. Maddox, and E. Wishinski. 1994. Temporal pattern in larval supply of summer-recruiting reef fishes to Lee Stocking Island, Bahamas. Mar. Ecol. Prog. Ser, 112: 75-86. 
Whitten, T., G.S. Henderson, and M. Mustafa. 1987. The Ecology of Indonesia Series Vol. IV. Periplos Edition(HK) Ltd., 754pp.

Williams, G.D., and R.M. Thom. 2001. Development and Guidlines for Aquatic Habitat Protection and Restoration: Marine and Esrtuarine Shoreline
ModificationIssues. Prepared for the Washington State Department of Transportation, Washington Department of Fish and Wildlife, and the Washington Department of Ecology, by Battelle Marine Science Laboratory, Sequim, Washington. 